\title{
On the identity of some endemic SW Asian Cruciferae. I. Thlaspi s. I.
}

\author{
D. A. German ${ }^{1,2}$ \\ ${ }^{1}$ Department of Biodiversity and Plant Systematics, Centre for Organismal Studies, Heidelberg University, \\ Im Neuenheimer Feld, 345, D-69120 Heidelberg, Germany \\ ${ }^{2}$ South-Siberian Botanical Garden, Altai State University, Lenin Ave., 61, 656049, Barnaul, Russia. \\ E-mail: oreoloma@rambler.ru
}

Keywords: Brassicaceae, Coluteocarpeae, Iran, Noccaea, Noccidium, rare species, synonyms, taxonomy, Thlaspideae, Turkey.

Summary. Identity of five poorly known SW Asian mustard species is revised. One, Aethionema bourgaei, is proven not to be conspecific with Noccaea oppositifolia and recognized as $N$. bourgaei, comb. nova. Other four are newly found to be synonymous with what follows them in parentheses: Noccidium tuberculatum (N. hastulatum), Thlaspi inhumile and Th. maassoumii (Noccaea trinervia), and Th. kochianum (Th. huetii). Comments on the type material or typification of some of the discussed taxa are provided where appropriate.

\section{О видовой самостоятельности некоторых эндемичных юго-западноазиатских крестоцветных (Cruciferae). I. Thlaspi s. I.}

\author{
Д. А. Герман ${ }^{1,2}$ \\ ${ }^{1}$ Кафедра биоразнообразия и систематики растений, Центр исследований организмов, Гейдельбергский университет, \\ Нойенхаймер Фельд, 345, г. Гейдельберг, D-69120, Германия \\ ${ }^{2}$ Южно-Сибирский ботанический сад, Алтайский государственный университет, \\ пр. Ленина, 61, г. Барнаул, 656049, Россия
}

Ключевые слова: Brassicaceae, Coluteocarpeae, Noccaea, Noccidium, Thlaspideae, Иран, редкие виды, синонимы, систематика, Турция.

\begin{abstract}
Аннотация. Проанализирована самостоятельность пяти видов крестоцветных, четыре из которых, до настоящего момента считавшиеся локальными юго-западноазиатскими эндемиками, предложено рассматривать в составе соответствующих таксонов, указанных после каждого из них в скобках: Noccidium tuberculatum (N. hastulatum), Thlaspi inhumile и Th. maassoumii (Noccaea trinervia), Th. kochianum (Th. huetii). Напротив, Aethionema bourgaei, долгое время числившийся среди синонимов Noccaea oppositifolia, хорошо отличается от последнего и восстановлен под названием $N$. bourgaei, comb. nova. Приведены критические замечания относительно типового материала либо типификации некоторых из рассмотренных названий.
\end{abstract}

Endemic species sufficiently contribute to biodiversity and, being especially threatened due to their limited distribution and often stenotopy, require accurate assessment of their status in order to increase the efficiency of nature protection worldwide. From theoretical viewpoint, patterns of neo- or palaeoendemism are helpful for understanding the details and driving forces of biota evolution and other biodiversity-related phenomena. However, it is not uncommon that information on the endemic species is scarce and/or outdated and this decreases the quality of knowledge on particular taxonomic groups and relevant regional floras, also hampering adequate practical biodiversity protection measures. Note- 
worthy, while with additional data becoming available, many poorly-known endemics prove to be distinct, "true" species, it is not rare that others turn out to represent at best slightly unusual specimens of previously discovered and often more widely distributed ones. Therefore, checking the taxonomic status of such understudied entities is apparently a useful task.

In the course of ongoing studies on the project BrassiBase, it became possible to revise the identity of some little-known Cruciferae species predominantly described from and known as local endemics of certain regions of South-West Asia. Considerable percent of them turned out to belong to the tribes Coluteocarpeae V. I. Dorof. and Thlaspideae DC. representing the taxa of traditionally circumscribed Thlaspi L. s. 1. Based on this common ground, they are assembled together and included into the present communication, the first of presumably two.

The basis for the study was herbarium specimens deposited at B, JE, LE, and W; high-quality digital images available via the Global Plants portal (http:// plants.jstor.org); and photos kindly provided by colleagues. For one taxon, no material was found and its identity could only be established based on the interpretation of original description. As a result, four out of five revised species are found conspecific with other, much more broadly distributed members of SW Asian Cruciferae. Use of an inadequate material (e. g., a single and poor specimen or gathering), overemphasizing the value of certain characters, and sometimes failure of finding the proper relationship are the main reasons of description of these taxa. On the other hand, in view of the fact that many groups of mustards are taxonomically problematic in which morphological discrimination of species is very difficult [and Thlaspi s. 1. is just the case], it can be admitted that some solutions presented in this communication might not be final, e. g., with respect to the status of Aethionema bourgaei Boiss., the single taxon restored here at the rank of distinct species from long-accepted synonymy. In any case, it seems reasonable to provide new considerations on the discussed taxa rather than keep treating them as either enigmatic narrow endemics of uncertain taxonomic and conservation status or synonyms of what they definitely not conspecific with.

All newly synonymized names were already included as such into the recently released "BrassiBase checklist version 1.0" (issued August 1, 2017) [http://brassibase.cos.uni-heidelberg.de/?action =tax; downloadable for registered users] but without any comments and evidences which are provided herein.

\section{Coluteocarpeae: Noccaea and Noccidium}

\section{1a. Noccaea}

Noccaea bourgaei (Boiss.) D. A. German, comb. nov. $\equiv$ Aethionema bourgaei Boiss., 1867, Fl. Or. 1: 344.

Syntypes: "[Turkey C2 Muğla/Antalya:] Plantae Lyciae. Mt. Ak-Dagh. Région alpine supérieur dans les pierrailles. 5 Juillet 1860. E. Bourgeau" (P 00428103 [http://plants.jstor.org/ stable/viewer/10.5555/al.ap.specimen.p00428103], P 01817608 [http://plants.jstor.org/stable/viewer/ 10.5555/al.ap.specimen.p01817608]).

Among all critical taxa considered in this communication, Ae. bourgaei is the only one which has been synonymized previously, but that synonymy cannot be retained and needs to be corrected. Hedge (Davis et al., 1965; Hedge, 1965) broadly circumscribed Ae. oppositifolium (Pers.) Hedge to include both Ae. rubescens Boiss. [currently Noccaea rubescens (Boiss.) F. K. Mey.] and Ae. bourgaei as synonyms. Meyer $(1973,2006)$ disagreed with regards to Ae. rubescens, transferred by him to Noccaea Moench, and this viewpoint gradually became dominating (Greuter, Burdet in Greuter, Raus, 1983 [as Thlaspi rubescens (Boiss.) Greuter et Burdet]; Marhold, 2011; Al-Shehbaz, 2014) though Hedge's concept can still be found in rather recent sources (e. g., Ertuğrul, 2012; The Plant List, 2013). Unlike Ae. rubescens, Ae. bourgaei was not revised by Meyer and it is still found exclusively among the synonyms of Ae. oppositifolium [nowadays Noccaea oppositifolia (Pers.) Al-Shehbaz et Menke] (Zohary et al., 1980; Greuter et al., 1986; Warwick et al., 2006; Marhold, 2011; Ertuğrul, 2012; Tropicos.org; etc.). However, Ae. bourgaei has also to be excluded from synonymy of N. oppositifolia because, unlike the latter species, it apparently does not form dense mats and has bright-green [badly dried specimens disregarding] (vs. grayish-green) leaves of "normal" (vs. rigid) texture and obscure (vs. prominent) venation, those of vegetative shoots and lowermost cauline ones attenuate into a narrow petiole (vs. all sessile) and not persistent (vs. persistent and becoming dark) upon withering. Hence, despite a superficial resemblance, Ae. bourgaei is clearly distinct from $N$. oppositifolia and differs from the latter by the same characters as $N$. rubescens. Therefore, it should be compared with $N$. rubescens and its closest relative, $N$. sintenisii (Hausskn. ex Bornm.) F. K. Mey. [Thlaspi sintenisii Hausskn. ex Bornm.] with both of which it looks extremely alike. Similarity to Ae. rubescens was mentioned yet in the protologue of Ae. bourgaei where it was distinguished solely by opposite [stem] leaves 
vs. alternate in the prior species (Boissier, 1867: 344). In fact, the character of leaf arrangement cannot be taken with full reliance since original material of Ae. bourgaei includes plants with both opposite and alternate leaves on flowering/fruiting stems and some individuals combine both states. Furthermore, according to the recently published key (Al-Shehbaz, 2014), Ae. bourgaei can be only determined as $N$. rubescens due to short (to $0.7 \mathrm{~mm}$ ) styles and relatively broad silicles (to $3.8 \mathrm{~mm}$ vs. to $3.0 \mathrm{men}$ tioned for in $N$. sintenisii [although this character seems to be badly reliable since in some syntypes of the latter species the silicles are also almost $4 \mathrm{~mm}$ wide]). On the other hand, N. rubescens [incl. Thlaspi crassum P. H. Davis] is only known thus far from the eastern part of Central Taurus (Davis, 1988; Parolly, 1995; Meyer, 2006) and the plants of Ae. bourgaei are somewhat more elegant and possess in general narrower (predominantly narrowly ovate to rhomboid-obovate vs. ovate or obovate in N. rubescens), minutely and obtusely (vs. more prominently and acutely to obtusely) auriculate or even partly non-auriculate stem leaves, and in this respect they resemble $N$. sintenisii in which, besides, middle stem leaves are also sometimes opposite (not so in $N$. rubescens). Furthermore, $N$. sintenisii is the only species out of the discussed two which is reported for Ae. bourgaei area. It was long know as a rare plant endemic to the north-eastern part of Turkey (Bornmüller, 1936; Hedge, 1965; Meyer, 2006) until several gatherings from Western and westernmost Central Taurus including Lycian Akdağ [the type locality of Ae. bourgaei] were assigned to this species (Parolly, 1995; Parolly, Eren, 2006). Relevant specimens (B!) indeed remind $N$. sintenisii though they are characterized by generally slightly shorter styles (0.8-1.1 vs. (0.8) $1.2-2.1 \mathrm{~mm}$ in plants from locus classicus). Unfortunately, collection from Akdağ (Döring et al., No. 6217 - B 10 0274435!) consists of plants with first flowers only and style length cannot be checked, but in the gathering from Davraz Dağ 1 (Eren \& Parolly, No. 7646 - B 10 0208568!) among numerous medium-length-styled plants there is one with all styles being just $0.4-0.5 \mathrm{~mm}$, i. e. corresponding both Ae. bourgaei and N. rubescens but not $N$. sintenisii. Thus, Ae. bourgaei (and in general collections from Western/westernmost Central Taurus) appears somewhat intermediate between the two discussed Noccaea species and with such uncertain picture at hand it is uneasy to make sound conclusion regarding its status. Therefore, it is only excluded from synonymy of evidently neither conspecific nor closely related $N$. oppositifolia and kept as a separate species at least until more material and desirably molecular phylogenetic information is available in order to re-evaluate diagnostic characters and properly maintain its relationship and status with regards to $N$. rubescens and $N$. sintenisii.

Noccaea trinervia (DC.) Steud., 1841, Nomencl. Bot., ed. 2, 2: 197. $\equiv$ Hutchinsia trinervia DC., 1821, Reg. Veg. Syst. Nat. 2: 387. $\equiv$ Iberidella trinervia (DC.) Boiss., 1842, Ann. Sci. Nat., Bot. Sér. 2, 17: 188. $\equiv$ Aethionema trinervium (DC.) Boiss., 1867, Fl. Or. 1: 342. 三 Eunomia trinervia (DC.) Prantl, 1891, Nat. Pflanzenfam. 3(2): 165. $\equiv$ Thlaspi trinervium (DC.) Mozaff., 1996, Iranian J. Bot. 7: 139. $\equiv$ Vania trinervia (DC.) Khosravi et al., 2009, Ann. Missouri Bot. Gard. 96(4): 570, comb. illeg.

Lectotype (Khosravi et al., 2009b: 570): "[Iran. Alwand Kuh:] Mont Elwind. [Olivier et Bruguière], [ex] herb. Olivier [obtained in] 1822" (G-DC: G 00131229! [http://plants.jstor.org/stable/viewer/10.5555/al.ap.specimen.g00131229], isolecto - P 00633350).

= Thlaspi inhumile Ponert, 1972, Preslia 44(3): 272, syn. nov.

Type: "Iran. Montes Elborz, pars meridionalis, inter oppida Gachsar et Mazan-abad, declive boreale argillosum, $2650 \mathrm{~m}$ supra mare. 25 VII 1970. J. Ponert, No. 38408/58" (BATU? PR?, iso - ?).

Note 1. The type material of Th. inhumile (holoand isotype) was said to be deposited in BATU: "Typi in herbario Horti botanici Batumensis conservatur" (Ponert, 1972). However, it was not found there and no relevant information is available in the herbarium database (Nino Memiadze, pers. comm. by e-mail, April 20, 2017). Some gatherings of J. Ponert are stored in PR but they are not yet prepared for inclusion into the collection and therefore inaccessible for study (Jiří Danihelka and Otakar Šída, pers. comm. by e-mail, April 24, 2017). Thus, material of Th. inhumile might theoretically be found in future in PR but for the moment its identification is only possible via the protologue which is fortunately informative enough and includes leaf, fruit, and seed illustrations.

Description of Thlaspi inhumile was published by the time of submission of Meyer's (1973) first revision and the species was not included in either that or any of his subsequent works. To my knowledge, it was also not treated critically by other authors and appears accepted in all relevant sources (Zohary et al., 1980; Akhani, 2003; Warwick et al., 2006; The Plant List, 2013; GBIF; Tropicos.org; etc.).

The species was initially assigned to Thlaspi sect. Apterigium Ledeb. and, due to its long, to 4.5 
mm, style, compared with Th. rostratum N. Busch [Noccaea rostrata (N. Busch) Al-Shehbaz] and distinguished from the latter by stout, suffrutescent habit, amplexicaul leaves, longer pedicels, etc. In fact, by very characteristic life form, leaf shape, pattern of venation and further features, the description perfectly matches $N$. trinervium s. 1 . with the only exception of the number of ovules per locule (2, rarely 3 vs. strictly 2 ) and cotyledonary position (accumbent vs. incumbent). However, with the following considerations in mind, these deviations do not seem to be critical to refute the proposed identification of Th. inhumile. Although the number of ovules ( 2 in a locule) and character of placentation (apical) are constant in $N$. trinervium and allied species, occasional abnormalities are possible. For example, locules with 3 ovules were detected by the present author in the specimen of $N$. oppositifolia collected by I. Hagemann et al. (No. 2815) on $12 \mathrm{X}$ 1984 in Bursa, Uludağ (B 100157870 !). Interestingly, placentation of all 3 locules left apical, and Ponert also mentioned "semina ... ab funiculis inaequilongis ex angulo superiore loculi pedentia". It is likely that he observed the same aberration as was found in the above specimen of $N$. oppositifolia. As for cotyledonary position, although all specimens of $N$. trinervium studied by me are characterized by exclusively incumbent radicle, it is known that this feature is variable in Noccaea s. 1. and sometimes show variability among closely related congeners or even within a species (Hedge, 1961). As indicated by the latter author, this is particularly true for $T h$. kurdicum Hedge s. 1. later recognized as three species of Vania F. K. Mey. (Meyer, 1973) to which N. trinervium was found to be closest morphologically and phylogenetically (Khosravi et al., 2009b).

Under a narrow species concept not followed here, Th. inhumile due to its profoundly auriculate leaves would have been assigned to Aethionema sagittatum (Boiss.) Boiss.; the same is true for the following taxon.

= Thlaspi maassoumii Mozaff., 1996, Iranian J. Bot. 7(1): 135. $\equiv$ Noccaea maassoumii (Mozaff.) Al-Shehbaz, 2014, Harvard Pap. Bot. 19(1): 41, syn. nov.

Type: "Flora of Iran. Prov. Mazandaran: S of Ramsar, Siemam (Mt. 3620 m). Alt. 3600 m. N exposed cliffs. 13. 08. 1976. Runemark \& Maassoumi, No. 21825" (TARI, photo!).

This species was published without a diagnosis (Mozaffarian, 1996) and, similarly to most of the taxa discussed here, has not been formally synonymzied yet, although Akhani (2003) noted that it is "very close to the very polymorphic Aethionema trinervium (DC.) Boiss. and probably conspecific with it". According to the recent sources, Th. maassoumii is still known from the locus classicus only (Noroozi, 2014) and differs from $N$. trinervia in 1-veined (vs. 3-veined) leaves and petals 5 (vs. 6-10) mm long (Al-Shehbaz, 2014). In fact, leaves of $N$. trinervia often have more than 3 (5-7-9) veins of which central and nearest lateral ones are the longest and most prominent. Although the quality of the photo of the type I have studied is moderate and most of leaves are longitudinally folded (or with involute margins) after drying, it is discernable that they are definitely several-veined. The petals are absent on the type and apparently were described from the paratype (Runemark \& Maassoumi, No. 21819 [TARI]) which I have not seen. According to the drawing (Mozaffarian, 1996: 136), the latest flowers only could be studied which are know to be of minimal size in various representatives of the family. Hence, there is clearly no possibility to distinguish Th. maassoumii from $N$. trinervia based on the mentioned characters and no other aspect of the description seems to justify it as well. A condensed, subpulvinate habit agrees with the appearance of high-mountain specimens of the species (Khosravi et al., 2009b), enormous morphological variability of which is beyond the scope of the present communication.

\section{1b. Noccidium}

Noccidium hastulatum (DC.) F. K. Mey., 1973, Feddes Repert. 84(5-6): 456. 三Hutchinsia hastulata DC., 1821, Reg. Veg. Syst. Nat. 2: 388. 三 Noccaea hastulata (DC.) Steud., 1841, Nomencl. Bot., ed. 2, 2: 196. $\equiv$ Carpoceras hastulatum (DC.) Boiss., 1849, Diagn. P1. Or. Nov., ser. 1, 2(8): 38. $\equiv$ Thlaspi hastulatum (DC.) Hedge in Rechinger, 1968, Fl. Iranica 57: 115.

Lectotype (Meyer, 2003: 117): "[Azerbaijan:] Lepidium chalapense Gmelinianum. Nonne genus distinctum ob apicem siliquo? Num vera siliqua? An silicula elongata? Lenkheran. [Hansen, ded.] mr. Fischer." (G-DC: G 00202416 [http://plants. jstor.org/stable/viewer/10.5555/al.ap.specimen. g00202416]).

= Noccidium tuberculatum F. K. Mey., 1973, Feddes Repert. 84(5-6): 456, syn. nov.

Type: "[Iran:] Persia borealis: Kandavan (Elburs), trockene Hänge, alt. 2400 m. s. m. 9 VI 1937. D. E. Gauba, No. 1336" (B!, iso - JE 0004199! [http://plants.jstor.org/stable/viewer/10.5555/al.ap. specimen.je00004199]). 
This species has also been described without a diagnosis (Meyer, 1973) based on the single gathering from the middle (interpreted as upper) belt of Elburs range. Later (Meyer, 2003), another three collections, all from Elburs as well, were added (JE!, $\mathrm{W}$ !), and the characters distinguishing $N$. tuberculatum from $N$. hastulatum were clarified (modified from Meyer, 2003):

1. Plant annual to perennial, taproot slender. Stem 9-50 cm high, usually ascending and branched, glabrous throughout. Style $0.7-1.3 \mathrm{~mm}$ long; seeds $1.35-1.5 \times 0.85-1 \mathrm{~mm}$. Rocky, gravelly, and sandy habitats as well as forests of montane belt

$N$. hastulatum

+ Plant perennial, taproot stout. Stems to $12 \mathrm{~cm}$ high, erect, simple, basally covered with papilloid tubercles. Style $0.5-0.7 \mathrm{~mm}$ long; seeds $1.55-1.75 \times$ 1.1-1.25 mm. Dry slopes of alpine belt

N. tuberculatum

Based on these data, N. tuberculatum appears a rare species confined to the eastern portion of the distribution area of the genus Noccidium F. K. Mey., occurring in general at higher elevations than more widely distributed $N$. hastulatum (1600-2400 vs. 1250-1900 m a. s. 1.), much more stenotopic compared to its congener and peculiar for a combination of the above-mentioned morphological characters. Revision of sufficient material ruins this picture and demonstrates that neither relevant character combination always holds nor there is any correlation of such features with geography and ecology. For example, the following specimens: "Prov. Masandaran: in valle fluvii Talar, in silvis. F. Starmühlner, No. 299. 20 XI [19]49" (W 1963-4065!); "Prov. Gilan (olim Talysch): in silvis prope Astara. F. Starmühlner, No. 273. 16 X [19]49" (W 1963-4064!); "Masanderan mts., northern slope, near Germ-Abda...[unclear], mixed forest. 9 X 1903. G. Gadd, No. 36" (LE!); "Reliq. Fischer. Persia. Hutschinsia" (LE!) have stems in lower part (and branches proximally) clearly covered with numerous tubercles and thus possess the most characteristic feature of N.tuberculatum. At the same time, they are annuals with moderately to abundantly branched stems $20 \mathrm{~cm}$ alt. and taller (67 cm in Gadd's specimen) collected in the forest and in this respect corresponding $N$. hastulatum (both specimens at $\mathrm{W}$ bear relevant identification of Meyer and were cited by him in 2003 under this name). All have styles mainly exceeding $0.7 \mathrm{~mm}$ long (predominantly ca. $1 \mathrm{~mm}$ to slightly longer), but in the specimen from Astara some styles are just $0.5 \mathrm{~mm}$ long; noteworthy, it originates from the western portion of the generic distribution area. Interestingly, in its duplicate from LE, also characterized by varying style length, stems are smooth. These evidences clearly show that $N$. tuberculatum represents a portion of morphological variability of $N$. hastulatum and taxonomical recognition of respective unstable assemblage of characters is unjustifiable.

Noccidium is nowadays being treated as a member of the tribe Camelineae DC. (Al-Shehbaz, 2012, 2014; Sagun, Auer, 2017). Such viewpoint is based on some phylogenetic studies (e. g., Khosravi et al., 2009a; Warwick et al., 2010) utilized previously published (Koch, Mummenhoff, 2001) ITS sequence (AF336164-AF336165) attributed to $N$. hastulatum. This placement apparently contradicts morphological evidences because members of Camelineae are characterized, in particular, by presence of indumentum of branched (sometimes mixed with simple) trichomes, actinomorphic flowers, and lack of papilloid tubercles. By contrast, unequal petals occur in some members of Coluteocarpeae as well as tubercles which are also known in the closely related Conringieae D. A. German et Al-Shehbaz. Phylogenetic placement within the Coluteocarpeae clade found by Couvreur et al. (2010) based on the analysis of a mitochondrial marker (nad4 intron 1) looked therefore more reliable and it agrees with subsequently obtained signal from both nuclear (ITS) and chloroplast (trnL-F) markers (German, Koch, in prep.). Thus, the tribal assignment of the single species of Noccidium should be changed to Coluteocarpeae and it is a matter of further studies to decide whether it is reasonable to keep it separate from Noccaea or merge with the latter. Infraspecific variability of degree of development of tubercles revealed in $N$. hastulatum is not surprising and can be found in some representatives of both abovementioned related tribes, such as Noccaea iberidea (Boiss.) Al-Shehbaz et Menke or Zuvanda crenulata (DC.) Askerova. This may lead, as in case of Noccidium, to redundant description of some variants as species like, for example, Malcolmia glaberrima Rech. fil. et Esfand., a less tuberculate form of $Z$. crenulata synonymized with the latter by its author when more material became available for study (Rechinger, 1968, as M. crenulata (DC.) Boiss.).

\section{Thlaspideae: Thlaspi}

Thlaspi huetii Boiss., 1856, Diagn. P1. Or. Nov., ser. 2, 5: 39 . 
Syntypes: "[Turkey A8 Erzurum:] Armenia. Circà Tortum. Jun. 1853. Huet du Pavillon" (G00371929,G-BOISS:G00371966,GOET002659 [http://plants.jstor.org/stable/viewer/10.5555/al.ap. specimen.goet002659], JE 00000226! [http:// plants.jstor.org/stable/viewer/10.5555/al.ap. specimen.je00000226], JE 00000227! [http:// plants.jstor.org/stable/viewer/10.5555/al.ap.specimen.je00000227], JE 00000228! [http://plants. jstor.org/stable/viewer/10.5555/al.ap.specimen. je00000228], JE 00000229! [http://plants.jstor.org/ stable/viewer/10.5555/al.ap.specimen.je00000229], K 000484287 [http://plants.jstor.org/stable/viewer/ 10.5555/al.ap.specimen.k000484287],K000484288 [http://plants.jstor.org/stable/viewer/10.5555/al.ap. specimen.k000484288], LE (2×)!, P 01817546 [http://plants.jstor.org/stable/viewer/10.5555/al.ap. specimen.p01817546], WAG 0004281 [http:// plants.jstor.org/stable/viewer/10.5555/al.ap.specimen.wag0004281]).

Note 1. The G-BOISS specimen and unspecified material from $\mathrm{G}$ was cited by Meyer (2001: 21, "holotypus") and Dorofeyev (2012: 455, "typus"), respectively but, as long as Boissier (1856) referred to exsiccates and did not specify the herbarium, no holotype exists. As both citations do not meet the requirements of ICN Arts. 7.10 and 9.23 (McNeill et al., 2012), lectotypification is still needed for $T h$. huetii.

= Thlaspi kochianum F. K. Mey., 1973, Feddes Repert. 84(5-6): 451, syn. nov.

Type: "[Turkey A8 Erzurum:] Kisil-Kilissa, 8/9 43 [= 8 IX 1843]. K. Koch, No. 2002”'(B 100249988 ! [http://plants.jstor.org/stable/viewer/10.5555/al.ap. specimen.b_10_0249988], iso - JE 00000231! [http://plants.jstor.org/stable/viewer/10.5555/al.ap. specimen.je00000231]).

Like other species described by Meyer in his first treatment of Thlaspi s. 1., Th. kochianum lacks the diagnosis, but later (Meyer, 2001) the author provided the characters distinguishing it from Th. huetii. These included style length (0.9-1.2 vs. 0.6-0.7 $\mathrm{mm}$ ), fruit shape and size (orbicular, ca. 6 vs. suborbicular, 7-9 $\mathrm{mm}$ long) along with differences in the morphology of cells of the septum (from Meyer,
2001). It should be mentioned that, except for the styles, comparison of fruit characters of the two species is improper because material of Th. kochianum studied by Meyer includes the only plant (isotype is represented by its fragments) with flowers and few immature silicles. As for the style, a study of ample material (LE!, W!) shows that in Th. huetii it varies from 0.3 to $1.3 \mathrm{~mm}$ long and nearly complete range $(0.4-1.1 \mathrm{~mm})$ is demonstrated already by Huet's classical gathering(s). With this arguments and having in mind full coincidence in other characters (of leaves, pedicels, flowers), there is clearly no way to accept Th. kochianum as distinct from Th. huetii. The type of Th. kochianum is supplied with collector's label with the name "Thlaspi glaucophyllum C. Koch" and description but it was never published and the species remained undescribed until it was done by Boissier (1856).

In contrast to the data of Meyer (2001), a wide distribution in southern and south-eastern Turkey is reported for Th. kochianum by Mutlu (2012). This information is also incongruent with the geographic pattern of Th. huetii confined to north-eastern Turkey and adjacent Georgia and Armenia (Grossheim, 1950; Hedge, 1965; Meyer, 2001; Mutlu, 2012); apparently, relevant records belong to another species.

\section{Acknowledgements}

Robert Vogt, Sarah Bollendorff (B), Jochen Müller (JE), Leonid V. Averyanov, Vladimir I. Dorofeyev, Galina L. Kudryashova, Ivan V. Tatanov, Valeriya V. Shvanova (LE), Ernst Vitek, and Bruno Wallnöffer (W) are acknowledged for providing the opportunity of studying the collections; Jiří Danihelka, Ali Dönmez, Marcus A. Koch, Dmitry V. Geltman, Eugeny V. Boltenkov, and Nikolai W. Friesen for help with literature; Hamid Moazzeni for the photo of the type of Thlaspi maassoumii; Nino Memiadze (BATU), Otakar Šída (PR), and Jiř́i Danihelka for the information regarding original material of Th. inhumile. Support by the German Research Foundation (Deutsche Forschungsgemeinschaft, DFG) (grant KO2302-13 to Marcus A. Koch) is highly appreciated as well.

\section{REFERENCES / ЛИТЕРАТУРА}

Akhani H. 2003. Notes on the flora of Iran: 4. Two new records and synopsis of the new data on Iranian Cruciferae since Flora Iranica. Candollea 58(2): 369-385.

Al-Shehbaz I. A. 2012. A generic and tribal synopsis of the Brassicaceae (Cruciferae). Taxon 61(5): 931-954. URL: http://www.jstor.org/stable/41679341 
Al-Shehbaz I. A. 2014. A synopsis of the genus Noccaea (Coluteocarpeae, Brassicaceae). Harvard Pap. Bot. 19(1): 25-51. DOI: 10.3100/hpib.v19iss1.2014.n3

Boissier E. 1856. Diagnoses plantarum Orientalium novarum. Ser. 2, 3(5). Lipsiae [Leipzig]: B. Herrmann [\& Genève: Typis Ramboz et Schuchardt]. 118 pp.

Boissier E. 1867. Flora Orientalis. Vol. 1. Basel \& Genève: H. Georg. XXXIV + 1017 pp. DOI: 10.5962/bhl. title. 20323

Bornmüller J. 1936. Symbolae ad floram anatolicam. Feddes Repert., Beih. 89(1): 1-258.

Couvreur T. L. P., Franzke A., Al-Shehbaz I. A., Bakker F., Koch M. A., Mummenhoff K. 2010. Molecular phylogenetics, temporal diversification and principles of evolution in the mustard family (Brassicaceae). Mol. Biol. Evol. 27(1): 55-71. DOI: $10.1093 / \mathrm{molbev} / \mathrm{msp} 202$

Davis P. H., Cullen J., Coode M. J. E., Hedge I. C. 1965. Materials for a Flora of Turkey: X. Notes Royal Bot. Gard. Edinburgh 26(2): 165-201.

Davis P. H., Mill R. R., Tan K. (eds.). 1988. Flora of Turkey and the East Aegean Islands. Vol. 10. Supplement. Edinburgh University Press, Edinburgh, XXI + 429 pp.

Dorofeyev V. I. 2012. Brassicaceae Burnett, nom. cons., nom. alt. (Cruciferae Juss., nom. cons.). In: Conspectus florae Caucasi. Ed. A. L. Takhtajan.Vol. 3(2). KMK Scientific Press, St. Petersburg - Moskow. Pp. 371-469 [In Russian].

Ertuğrul K. 2012. Aethionema Aiton. In: Türkiye Bitkileri Listesi (Damarl Bitkiler) [A checklist of the flora of Turkey (vascular plants). Eds. A. Güner, S. Aslan, T. Ekim, M. Vural, M. T. Babaç]. Nezahat Gökyigit Botanik Bahçesi ve Flora Arastırmaları Dernegi yaymı, Istanbul. Pp. 246-248 [In Turkish].

GBIF Secretariat: GBIF Backbone Taxonomy. doi:10.15468/39omei. URL: http:/www.gbif.org/species/3052715 (Accessed 19 September 2017).

Grossheim A. A. 1950. Flora Kavkaza [Flora of Caucasus]. Ed. 2. Vol. 4. Nymphaeaceae - Platanaceae. Publishers of Academy of Sciences of USSR, Moscow - Leningrad, $311+$ [178] + XXI pp. [In Russian].

Greuter W., Raus T. (eds.). 1983. Med-Checklist notulae, 7. Willdenowia 13(1): 79-96.

Greuter W., Burdet H. M., Long G. (eds.). 1986. Med-Checklist. Vol. 3. (Convolvulaceae - Labiatae). Genève: Conservatoire et Jarin botniques de la Ville de Genève. I-XVI + 395 + XVII-CXXIX pp.

Hedge I. C. 1961. Materials for a Flora of Turkey: V. Notes Royal Bot. Gard. Edinburgh 23(4): 547-558.

Hedge I. C. 1965. Aethionema R. Br., Thlaspi L. In: Flora of Turkey and the East Aegean Islands. Ed. P. H. Davis. Vol. 1. [Edinburgh] University Press, Edinburgh. Pp. 314-330, 330-341.

Khosravi A. R., Mohsenzadeh S., Mummenhoff K. 2009a. Phylogenetic relationships of Old World Brassicaceae from Iran based on nuclear ribosomal DNA sequences. Biochem. Syst. Ecol. 37(2): 106-115. DOI: 10.1016/j. bse.2009.01.010

Khosravi A. R., Jacquemoud F., Mohsenzadeh S., Menke M., Mummenhoff K. 2009b. Phylogenetic position and taxonomic classification of Aethionema trinervium (Brassicaceae): A morphologically variable subshrub from Southwestern Asia. Ann. Missouri Bot. Gard. 96(4): 564-574. DOI: 10.3417/2007004

Koch M., Mummenhoff K. 2001. Thlaspi s. str. (Brassicaceae) versus Thlaspi s. 1.: morphological and anatomical characters in the light of ITS nrDNA sequence data. Pl. Syst. Evol. 227(3-4): 209-225. DOI: 10.1007/s006060170049

Marhold K. 2011. Brassicaceae. In: Euro +Med: Euro +Med PlantBase-the information resource for Euro-Mediterranean plant diversity. URL: http://ww2.bgbm.org/EuroPlusMed (Accessed 20 September 2017).

McNeill J., Barrie F. R., Buck W. R., Demoulin V., Greuter W., Hawksworth D. L., Herendeen P. S., Knapp S., Marhold K., Prado J., Prud'homme van Reine W. F., Smith G. F., Wiersema J. H., Turland N. J. 2012. International Code of Nomenclature for algae, fungi, and plants (Melbourne Code). Adopted by the Eighteenth International Botanical Congress Melbourne, Australia, July 2011. Königstein: Koeltz Scientific Books. XXX + 208 pp. [Regnum Vegetabile. Vol. 154].

Meyer F. K. 1973. Conspectus der “Thlaspi"-Arten Europas, Afrikas und Vorderasiens. Feddes Repert. 84(5-6): 449-470. DOI: 10.1002/fedr.19730840503

Meyer F. K. 2001. Kritische Revision der “Thlaspi”-Arten Europas, Afrikas und Vorderasiens. I. Thlaspi L. Haussknechtia 8: 3-42.

Meyer F. K. 2003. Kritische Revision der “Thlaspi”-Arten Europas, Afrikas und Vorderasiens. V. Noccidium F. K. Mey. Haussknechtia 9: 115-124.

Meyer F. K. 2006. Kritische Revision der "Thlaspi"-Arten Europas, Afrikas und Vorderasiens. IX. Noccaea Moench. Haussknechtia 12, Beih.: 1-343.

Mozaffarian V. 1996. Studies on the flora of Iran, new species, new combinations and new records. Iranian J. Bot. 7(1): 127-142.

Mutlu B. 2012. Thlaspi L. In: Türkiye Bitkileri Listesi (Damarlı Bitkiler) [A checklist of the flora of Turkey (vascular plants) Eds. A. Güner, S. Aslan, T. Ekim, M. Vural, M. T. Babaç]. Nezahat Gökyigit Botanik Bahçesi ve Flora Arastırmaları Dernegi yaymı, Istanbul. Pp. 297-299 [In Turkish]. 
Noroozi J. 2014. Iran. In: Red list of the endemic plants of the Caucasus: Armenia, Azerbaijan, Georgia, Iran, Russia, and Turkey. Eds. J. Solomon, T. Shulkina, G. E. Schatz [Monographs in systematic botany from the Missouri Botanical Garden (MSB), vol. 125]. Missouri Botanical Garden Press, St. Louis. Pp. 149-177.

Parolly G. 1995. New taxa and noteworthy records from the Western and Middle Taurus Range, Turkey. Willdenowia 25(1): 239-252. URL: http://www.jstor.org/stable/3996985

Parolly G., Eren Ö. (eds.). 2006. Contributions to the flora of Turkey, 1. Willdenowia 36(2): 823-844. DOI: 10.3372/wi.36.36213

Ponert J. 1972. A new species of Thlaspi from Iran. Preslia 44(3): 272-273.

Sagun V. G., Auer C. 2017. Pollen morphology of selected Camelineae (Brassicaceae). Palynology 41(2): 255266. DOI: $10.1080 / 01916122.2016 .1163517$

Rechinger K. H. 1968. Tribus Hesperideae. In: Flora Iranica. Ed. K. H. Rechinger. Vol. 57. Academische Drucku. Verlagsanstalt, Graz. Pp. 251-308.

The Plant List. 2013. Version 1.1. URL: http://www.theplantlist.org (Accessed 24 September 2017).

Tropicos.org. [2017]. Missouri Botanical Garden. URL: http://www.tropicos.org (Accessed 23 September 2017).

Warwick S. I., Francis A., Al-Shehbaz I. A. 2006. Brassicaceae: Species checklist and database on CD-Rom. Plant Syst. Evol. 259(2-4): 249-258. DOI: 10.1007/s00606-006-0422-0

Warwick S. I., Mummenhoff K., Sauder C. A., Koch M. A., Al-Shehbaz I. A. 2010. Closing the gaps: phylogenetic relationships in the Brassicaceae based on DNA sequence data of nuclear ribosomal ITS region. Pl. Syst. Evol. 285(3-4): 209-232. DOI: 10.1007/s00606-010-0271-8

Zohary M., Heyn C. C., Heller D. 1980. Conspectus florae orientalis. An annotated catalogue of the flora of the Middle East. Vol. 1. The Israel Academy of Sciences and Humanities, Jerusalem, 107 pp. 